\title{
PRAVNI POLOŽAJ POŠTENOG I NEPOŠTENOG POSJEDNIKA U ODNOSU NA VLASNIKA STVARI
}

Dr. sc. Jadranko Jug, sudac

Vrhovni sud Republike Hrvatske
UDK: 347.233

Ur.: 13. siječnja 2017.

Pr.: 5. veljače 2017.

Pregledni znanstveni rad

\section{Sažetak}

U radu se obrađuje problematika vezana uz pravni položaj poštenog $i$ nepoštenog posjednika u odnosu na vlasnika stvari, odnosno analiziraju se prava koja pripadaju posjedniku stvari i zahtjevi koje posjednik može postaviti prema vlasniku stvari kojem posjednik mora predati stvar. Također se s druge strane analiziraju prava i zahtjevi vlasnika stvari prema poštenom i nepoštenom posjedniku. Upraksi se pojavljuju dvojbe u svezi sodređivanjem nužnih i korisnih troškova koje je imao pošteni posjednik, koje su pretpostavke i do kada se može istaknuti pravo zadržanja radi naknade tih troškova, kada nastupa zastara takvog potraživanja i koliko su važne odredbe Zakona o obveznim odnosima u svezi sa stjecanjem bez osnove, poslovodstvom bez naloga ili pravom zadržanja, a koje reguliraju istu ili sličnu problematiku. Odgovore na neke od tih dvojbi dala je sudska praksa, slijedom čega je osnovna metoda u radu analiza $i$ istraživanje sudske prakse, posebno odluka Vrhovnog suda Republike Hrvatske.

Ključne riječi: pošteni posjednik, nepošteni posjednik, nužni i korisni troškovi, pravo zadržanja, stjecanje bez osnove, zastara.

\section{1. $U V O D$}

Posjednik stvari koji je nema pravo posjedovati i mora je predati vlasniku ima određena prava i obveze prema vlasniku stvari. ${ }^{1}$ Ta prava i obveze ovise prije svega o tomu je li posjednik stvari pošten ili nepošten zbog čega je od izuzetne važnosti utvrditi poštenje ili nepoštenje posjeda, odnosno posjednika. Posjed je pravno relevantna faktična vlast koju neka osoba ima glede određene stvari, ${ }^{2}$ a pravni poredak svojim normama određuje tu činjenicu kao pravnu, koja pod određenim pretpostavkama svojim postojanjem izaziva određene pravne učinke. ${ }^{3}$ Jedan od pravnih učinaka

1 V. čl. 164. i 165. Zakona o vlasništvu i drugim stvarnim pravima (Narodne novine, br. 91/96, 68/98, 137/99, 22/00, 73/00, 114/01, 79/06, 141/06, 146/08, 38/09, 153/09, 143/12 i 152/14 dalje ZV).

2 V. Gavella, N. et al.; Stvarno pravo, Svezak 1, 2. izmijenjeno i dopunjeno izd., Narodne novine, Zagreb, 2007., str. 151.

3 Gavella, op. cit., str. 227. 
posjeda stvari uređenje je prava i obveza posjednika prema vlasniku stvari, i kad je posjednik nema pravo posjedovati i mora stvar predati vlasniku. Pošteni posjednik u takvoj situaciji, osim što je dužan stvar predati vlasniku, ima znatno povoljniji položaj prema vlasniku, dok nepošten posjednik ima lošiji položaj sa znatno manje prava $i$ više obveza prema vlasniku stvari.

Pošteni posjednik, za razliku od nepoštenog, nije dužan vlasniku dati naknadu za uporabu stvari i koristi, a ne treba niti naknaditi ono što je eventualno kod tog korištenja i uporabe oštećeno ili uništeno. ${ }^{4}$ Pošteni posjednik može tražiti naknadu za nužne i korisne troškove koje je imao, dok nema pravo na naknadu tzv. luksuznih troškova u odnosu na koje ima pravo odnošenja, a ima i pravo zadržanja stvari dok mu troškovi ne budu naknađeni. ${ }^{5} \mathrm{~S}$ druge strane, nepošteni posjednik ima pravo samo na naknadu nužnih troškova koji bi bili nužni i vlasniku te ima pravo odnošenja za učinjene troškove ako to može učiniti bez oštećenja same stvari. ${ }^{6}$ Nepošteni posjednik nema pravo zadržanja stvari dok mu ne budu naknađeni troškovi. Za razliku od poštenog posjednika, nepošteni posjednik je dužan vlasniku stvari naknaditi svu štetu koja je nastala kao i koristi koje je imao za vrijeme posjedovanja stvari. ${ }^{7}$

S obzirom na bitno lošiji pravni položaj u pravima i obvezama nepoštenog posjednika u odnosu na vlasnika stvari, osnovno je kod ove problematike utvrditi subjektivno obilježje posjeda, a to je poštenje ili nepoštenje. Iako je definicija poštenog posjeda navedena u ZV-u, ${ }^{8} \mathrm{u}$ praksi se u svakom konkretnom slučaju procjenjuje kakvoća posjeda $s$ tog aspekta, a pri čemu je iznimno važna dosadašnja sudska praksa. Isto se odnosi na utvrđenje nužnih i korisnih troškova poštenog posjednika, odnosno nužnih troškova nepoštenog posjednika koji bi bili nužni samo za vlasnika, jer zakonodavac nije naveo definiciju tih troškova niti je naveo osnovne odrednice za njihovo utvrđenje. Daljnje sporno pitanje odnosi se na ispunjavanje pretpostavki za korištenje prava zadržanja poštenog posjednika stvari koju mora vratiti vlasniku i kakav je odnos odredbi ZV-a i Zakona o obveznim odnosima ${ }^{9}$ koji reguliraju istu problematiku.

Potraživanja poštenog i nepoštenog posjednika prema vlasniku stvari, kao i potraživanja vlasnika stvari prema nepoštenom posjedniku, u svojoj su osnovi obveznopravni zahtjevi koji korespondiraju s institutom stjecanja bez osnove ${ }^{10}$, a ponekad i s poslovodstvom bez naloga. ${ }^{11} \mathrm{U}$ sudskoj praksi se kontinuirano pojavljuju dvojbe oko konkurencije primjene čl. 164. i 165. ZV-a sa odredbama ZOO-a o stjecanju bez osnove, odnosno kada se odredbe o stjecanju bez osnove ili poslovodstva bez

4 V. čl. 164. st. 1. i 165. st. 1. ZV.

5 V. čl. 164. st. 2. i 4. ZV.

6 V. čl. 165. st. 3. i 5. ZV.

7 V. čl. 165. st. 1. i 4. ZV.

8 V. čl. 18. st. 3. $-6 . \mathrm{ZV}$.

9 Narodne novine, br. 35/05, 41/08, 125/11 i 78/15 - dalje ZOO. Pravo zadržanja za vjerovnika dospjele tražbine općenito je propisano u čl. 72. - 75. ZOO-a, ali isto tako ZOO propisuje posebno pravo zadržanja najmodavca kod ugovora o najmu (čl. 565. ZOO), izvođača kod ugovora o djelu (čl. 618. ZOO), pravo ugostitelja kod ugostiteljske ostave (čl. 742. ZOO) i pravo zastupnika kod ugovora o trgovinskom zastupanju (čl. 826. ZOO).

10 V. čl. 1111. - 1120. ZOO.

11 V. čl. 1122. - 1126. ZOO. 
naloga primjenjuju samostalno, a kada supsidijarno. To je posebno značajno zbog različitog roka zastarijevanja potraživanja temeljem stjecanja bez osnove u odnosu na ona koja propisuje ZV kod pravnog položaja poštenog i nepoštenog posjednika.

Sudovi u Republici Hrvatskoj (dalje RH) razvili su bogatu sudsku praksu u svezi s problematikom pravnog položaja poštenog i nepoštenog posjednika u odnosu na vlasnika stvari. Posebno je bitna sudska praksa Vrhovnog suda RH (dalje VSRH) jer se radi o najvišem sudu u RH čija je osnovna zadaća ujednačavanje sudske prakse i osiguranje jedinstvene primjene prava i ravnopravnosti svih u njegovoj primjeni. ${ }^{12} \mathrm{U}$ radu će se pokušati jasno definirati prava i obveze posjednika stvari koju je obvezan predati vlasniku kao i pretpostavke za primjenu čl. 164. i 165. ZV-a, odnosno izvršiti jasno razgraničenje $u$ odnosu na pretpostavke za primjenu propisa obveznog prava.

Osnovni cilj i svrha rada analiza je i cjeloviti prikaz instituta pravnog položaja poštenog i nepoštenog posjednika stvari te njihovih prava i obveza prema vlasniku stvari, i utvrđenje pretpostavki za primjenu odredbi ZV-a u sudskom postupku u odnosu na odredbe ZOO-a, radi otklanjanja eventualno preostalih dvojbi koje se pojavljuju u sudskoj praksi. Osnovna metoda koja se koristi u radu za ostvarenje cilja i svrhe rada uvid je u sudsku praksu, odnosno analiza odluka i sudske prakse VSRH-a i drugih sudova u RH. Svaki pravni sustav mora osigurati učinkovitu zaštitu prava vlasništva stvari, ali s druge strane mora osigurati i ostvarenje prava posjednika tih stvari ovisno o njihovom pravnom statusu temeljem faktične vlasti nad stvari.

\section{POSJEDNIKOVI PRIGOVORI PREMA VLASNIKU KOJI TRAŽI PREDAJU U POSJED STVARI}

U slučaju vlasničke tužbe (rei vindicatio) $)^{13}$ tuženik kao posjednik stvari može staviti određene prigovore koji se mogu podijeliti na one koji negiraju ili ukidaju vlasnički zahtjev (peremptorne) i na one koji zaustavljaju takav zahtjev (dilatorne). Peremptornim prigovorima kojima negira vlasnički zahtjev, tuženik se suprotstavlja vlasničkom zahtjevu tužitelja, tako da negira da je tužitelj stekao pravo vlasništva

12 V. čl. 119. st. 1. Ustava RH (Narodne novine, br. 56/90, 135/97, 8/98, 113/00, 124/00, 28/01, $41 / 01,55 / 01,76 / 10,85 / 10$ i 05/14) i čl. 20. st. 1. Zakona o sudovima (Narodne novine, br. 28/13, 33/15, 82/15 i 82/16 - dalje ZS).

13 V. čl. 162. ZV. Prava vlasnička tužba je tužba vlasnika protiv osobe koja posjeduje njegovu stvar, kojom on, pozivajući se na svoje pravo vlasništva koje je u stanju dokazati, traži od nje da mu ona preda svoj posjed te stvari (Gavella, op. cit., str. 592.). Klarić i Vedriš kraće i jednostavnije definiraju pravu vlasničku tužbu kao onu kojom vlasnik neposjednik zahtijeva od posjednika povrat individualne određene stvari (Klarić, P. i Vedriš, M.; Građansko pravo, Opći dio, stvarno pravo, obvezno i nasljedno pravo, 9. izmijenjeno i dopunjeno izd., Narodne novine, Zagreb, 2008., str. 294.). Kod prave vlasničke tužbe tužitelj treba dokazati svoje vlasništvo stvari, da se stvar nalazi u posjedu (faktičnoj vlasti tuženika) i mora dokazati identitet stvari. Općenito o tužbama za zaštitu prava vlasništva v. više u Jug, J., Tužbe za zaštitu prava vlasništva, Aktualnosti hrvatskog zakonodavstva i pravne prakse, Godišnjak 19, Organizator, Zagreb, 2012., str. 35. - 66. i Jelčić, O., Tužbe radi zaštite prava vlasništva, Hrvatska pravna revija, 2001. 
na stvari koja je predmet spora ${ }^{14}$ ili da on posjeduje tužiteljevu stvar. ${ }^{15} \mathrm{U}$ biti se radi o prigovorima nedostatka aktivne legitimacije tužitelja ili o promašenoj pasivnoj legitimaciji u odnosu na tuženika. Kod peremptornih prigovora koji ukidaju vlasnički zahtjev ne osporava se da je tužitelj imao pravo vlasništva na stvari koja je predmet spora, ali se tvrdi da mu je u vrijeme vođenja parnice pravo vlasništva prestalo postojati na temelju činjenica nastalih nakon stjecanja prava vlasništva. ${ }^{16}$

Dilatorni prigovori koji zaustavljaju vlasnički zahtjev su oni koji ne poriču da je tužitelj zaista vlasnik stvari koju zahtijeva, niti poriču da je tuženik posjednik te stvari, ali tvrde da tuženik ima pravo koje ga ovlašćuje na posjedovanje te tužiteljeve stvari. ${ }^{17}$ Takvim se prigovorom suprotstavlja vlasničkom zahtjevu tvrdnja o postojanju nekog tuženikovog prava koje ga ovlašćuje na nesamostalno posjedovanje stvari, a koje svojim postojanjem suspendira mogućnost izvršavanja vlasnikovog ovlaštenja da stvar ima u svom neposrednom posjedu. ${ }^{18} \mathrm{ZV}$ općenito navodi pravo posjednika odbiti predaju stvari njezinom vlasniku ako posjednik ima pravo koje ga ovlašćuje na posjedovanje te stvari. ${ }^{19}$ Tuženikovo pravo na posjed stvari može se temeljiti na određenom pravnom poslu obveznopravne ili stvarnopravne naravi, ali i temeljem zakona ili odluke suda ili tijela javne vlasti. ${ }^{20}$ Nadalje, pravo na posjed tuženika može proizlaziti iz prava prema samom vlasniku stvari, ali isto tako iz prava prema trećoj osobi koja ima pravo posjedovati vlasnikovu stvar ${ }^{21}$ ili od prava prema bivšem vlasniku od koji je pravo vlasništva prenio na sadašnjeg tužitelja. ${ }^{22}$ ZV predviđa i jedan prigovor posjednika koji je u naravi postupovnopravne naravi, i koji daje mogućnost neposrednom posjedniku koji drži predmet spora, pritom priznavajući

14 Ti prigovori ovisit će o tomu na koji način stjecanja prava vlasništva se tužitelj u tužbi poziva. Ako tužitelj tvrdi da je stekao pravo vlasništva dosjelošću, tuženik može dokazivati da tužitelj nije bio pošteni posjednik (jer se poštenje posjeda predmnijeva) ili da nije istekao zakonom određeni rok posjedovanja. Ako se tužitelj poziva na stjecanje prava vlasništva temeljem pravnog posla, tuženik može dokazivati da onaj tko je na tužitelja prenio pravo vlasništva nije bio vlasnik ili da je ništetan pravni posao na kojem tužitelj temelji stjecanje prava vlasništva.

15 Protiv vlasničke tužbe tuženik se može uspješno braniti prigovorom promašene pasivne legitimacije iz razloga što stvar koja je predmet spora nije u njegovu posjedu.

16 Sljedeći prigovori ukidaju vlasnički zahtjev: da je tuženik stekao pravo vlasništva poslije tužitelja (exceptio posterioris dominii), da je tužitelj otuđio stvar u svoje ime, dok ta stvar još nije bila njegova, a poslije ju je stekao u vlasništvo (čl. 161. st. 3. ZV), da je tužitelj prodao i predao stvar tuženiku, iako tuženik još nije postao vlasnikom (exceptio rei venditae et traditae).

17 Gavella, op. cit., str. 608.

18 Ibid.

19 V. čl. 163. st. 1. ZV.

20 Najčešće će to biti ugovori obveznopravne naravi sklopljeni između vlasnika i posjednika (zakup, najam, plodouživanje, posudba, zalog), ali se može raditi i o pravu retencije temeljem zakona (čl. 164. st. 2. ZV) ili stjecanju založnog prava temeljem sudske odluke i sl.

21 V. čl. 163. st. 2. ZV. Posjednik koji pravo na posjed izvodi od posrednog posjednika koji također ima pravo na posjed tužiteljeve stvari (primjerice zalog - podzalog, zakup - podzakup), može odbiti predati vlasniku stvar koju posjeduje. Takav prigovor će biti osnovan samo ako je treći, koji je tuženiku predao u posjed stvar, zakoniti nesamostalni posjednik te uz daljnji uvjet da je ovlašten dati u posjed vlasnikovu stvar trećoj osobi.

22 V. čl. 163. st. 3. ZV. U tom slučaju posjednik novom vlasniku stvari može istaknuti sve prigovore prava na posjed kao i bivšem vlasniku. 
višu vlast drugog posrednog posjednika iz čijeg posjeda izvodi svoj posjed, da može pozvati posrednog posjednika da stupi u parnicu umjesto njega. ${ }^{23}$

Ako posjednik stvari nije uspio s prigovorima prema vlasniku stvari koji negiraju, ukidaju ili zaustavljaju vlasnički zahtjev, i ako je jasno da mora predati stvar vlasniku, posjednik dolazi u određeni pravni položaj koji mu određuje daljnja prava i obveze prema vlasniku stvari, a koja ovise o subjektivnoj komponenti posjeda koja se sastoji od poštenja ili nepoštenja posjednika.

\section{PRAVA I OBVEZE POŠTENOG POSJEDNIKA PREMA VLASNIKU STVARI}

U čl. 164. ZV-a reguliran je pravni položaj poštenog posjednika koji nema pravo posjedovati vlasnikovu stvar i koji je mora predati vlasniku ili osobi koju vlasnik odredi. Pošteni posjednik u taj pravni položaj može doći nakon što je obvezan stvar vratiti vlasniku na temelju vindikacijskog zahtjeva i nakon što je stavio svoje protuzahtjeve u odnosu na troškove koje je imao tijekom poštenog posjeda stvari. Isto tako pošteni posjednik u isti položaj dolazi i ako je spreman dobrovoljno vratiti stvar vlasniku, ali nije postignut sporazum s vlasnikom stvari o naknadi troškova. Jedina prava obveza poštenog posjednika prema vlasniku stvari u takvoj je situaciji obveza predaje stvari vlasniku ili osobi koju odredi vlasnik. ${ }^{24} \mathrm{~S}$ druge strane pošteni posjednik ima pravo tražiti naknadu za nužne (impensae necessariae) i korisne (impensae utiles) troškove koje je imao tijekom posjeda stvari, a ima i pravo zadržati stvar dok mu vlasnik ne naknadi troškove. ${ }^{25}$ Pošteni posjednik nema pravo na naknadu troškova koji nisu bili ni nužni ni korisni (tzv. luksuzni troškovi), ali ima pravo odnošenja (ius tollendi) onog što je tim troškovima dodano stvari. ${ }^{26}$ Ukupno se može zaključiti da pravni položaj poštenog posjednika prema vlasniku stvari, u situaciji kad mora stvar predati vlasniku, daje poštenom posjedniku više prava nego obveza.

\subsection{Obveze poštenog posjednika prema vlasniku stvari}

Pošteni posjednik na temelju pravomoćno prihvaćenog vlasničkog zahtjeva ili dobrovoljno, dužan je vlasniku ili osobi koju on odredi, predati stvar u posjed. Pri tom se ona vlasniku stvari mora predati zajedno sa svim plodovima koji se od nje još nisu odvojili, te sa svim poboljšicama koje su u međuvremenu prirasle stvari. Međutim, pošteni posjednik nije dužan dati naknadu za to što je stvar upotrebljavao i od nje imao koristi, a nije dužan niti naknaditi ono što je na stvari oštećeno ili uništeno tijekom uporabe. Dakle, vlasnik stvari nema pravo od poštenog posjednika zahtijevati plodove i dijelove stvari koji su se odvojili od stvari u vrijeme dok je posjednik bio

23 V. čl. 163. st. 4. ZV. Radi se o imenovanju prethodnika (nominatio auctoris) koji institut regulira u čl. 210. Zakona o parničnom postupku (Narodne novine, br. 53/91, 91/92, 112/99, 88/01, $117 / 03,88 / 05,2 / 07,84 / 08,96 / 08,123 / 08,57 / 11,148 / 11,25 / 13$ i 89/14 - dalje ZPP).

24 V. čl. 164. st. $1 . Z \mathrm{ZV}$.

25 V. čl. 164. st. 2. ZV.

26 V. čl. 164. st. 2. ZV. To pravo poštenom posjedniku pripada samo ako stvar još nije vratio vlasniku i samo ako se odvajanjem ne oštećuje stvar. 
pošten, a nema pravo niti tražiti naknadu za njih kao i naknadu za uporabu i korištenje stvari za vrijeme trajanja poštenog posjeda. ${ }^{27}$ Stoga je u pravilu glavna i jedina obveza poštenog posjednika prema vlasniku stvari, predaja stvari u posjed vlasniku. Samo iznimno posjednik ima obvezu i naknade za uporabu i korištenje stvari ili za njeno oštećenje ili uništenje, ako bi bio obvezan i onda da je imao pravo na posjed za koji je vjerovao da mu pripada.

\subsection{Pravo poštenog posjednika na naknadu nužnih i korisnih troškova}

Pošteni posjednik ima pravo od vlasnika stvari koji zahtijeva predaju stvari tražiti nužne i korisne troškove koje je imao za vrijeme posjedovanja stvari. ${ }^{28}$ Stoga proizlazi da je pretpostavka za takvo potraživanje poštenog posjednika da vlasnik od njega potražuje predaju stvari ili da ju je pošteni posjednik već vratio vlasniku stvari dobrovoljno ili temeljem vindikacijskog zahtjeva. ${ }^{29}$ Argumentum a contrario u situaciji kada vlasnik stvari ne zahtijeva predaju stvari i posjednik i dalje posjeduje stvar, nema niti mjesta potraživanju poštenog posjednika za nužne i korisne troškove koje je eventualno imao temeljem odredbe čl. 164. st. 2. ZV-a. Tada pošteni posjednik može eventualno potraživati naknadu za nužne i korisne troškove ili druga ulaganja u stvar temeljem propisa obveznog prava i pravnog posla kojim eventualno ima pravo na posjed. ${ }^{30}$ Zahtjev poštenog posjednika za naknadu nužnih i korisnih troškova gledajući s postupovnopravnog aspekta može biti istaknut kao protuzahtjev i protutužba u postupku povodom vlasničke tužbe vlasnika stvari, a može biti istaknut kao samostalan zahtjev prema vlasniku stvari kojem pošteni posjednik tek treba vratiti stvar ili ju je već vratio.

ZV ne sadrži definiciju nužnih i korisnih troškova, već samo navodi da nije koristan onaj trošak kojim je pošteni posjednik promijenio namjenu stvari, ako to vlasniku nije korisno. ${ }^{31}$ Stoga se kod promjene namjene stvari učinjeni troškovi

27 ZV u čl. 164. st. 1. navodi da pošteni posjednik nije obvezan vlasniku stvari dati naknadu za upotrebljavanje stvari i za to što je od nje imao koristi primjereno onom pravu na posjed za koje je vjerovao da pripada. To znači da pošteni posjednik koji je stvar posjedovao smatrajući da mu pripada pravo na samostalan i neposredan posjed (vjerujući da mu pripada stvar kao vlasniku) neće morati vlasniku dati naknadu za oštećenje stvari, smanjenje vrijednosti ili uništenje, za odvojene plodove. Međutim, ako je pošteni posjednik posjedovao stvar kao posredni posjednik vjerujući da mu pripada neko ograničeno stvarno ili obvezno pravo (pravo najma ili založno pravo i sl.), a stvar je oštećena ili uništena, on bi bio obvezan naknaditi ili popraviti štetu jer bi je morao naknaditi i da je zaista imao pravo na posjed za koje je vjerovao da mu pripada. Isto se odnosi na naknadu za uporabu i korištenje.

28 V. čl. 164. st. 2. ZV.

29 O tomu v. odluku VSRH broj Rev-764/08 od 12. rujna 2012. i odluku VSRH broj Rev-1604/90 od 14. studenog 1990., htpps://sudskapraksa.csp.vsrh.hr, očitanje 2. veljače 2017. Tako se u odluci VSRH broj Rev-160/90 od 14. studenog navodi: tužiteljima kao posjednicima koji su izvršili ulaganje svojih dredstava u objekt tužene kao vlasnice (obzirom da ulaganje nuije izvršeno u ispunjnju zakonske ili ugovrne obveze), pripada pravo na naknadu troškova ulaganja tek od trenutka kada vlasnik zatraži povrat ili kad posjednici predaju vlasniku stvar (bez obzira da li je predaja dobrovoljna ili je rezultat provedenog izvršenja).

30 O tome v. infra pogl. 5.

31 V. čl. 164. st. 3. ZV. 
procjenjuju temeljem subjektivnog kriterija u odnosu na vlasnika stvari. Ako promjena namjene stvari nije korisna za vlasnika stvari, poštenom posjedniku se ne priznaju učinjeni troškovi. Nužni su oni troškovi koji su bili nužni za samo održanje stvari i bez njih bi stvar potpuno ili djelomično propala. ${ }^{32} \mathrm{U}$ svakom konkretnom slučaju potrebno je po objektivnom kriteriju utvrditi i procijeniti radi li se o nužnim troškovima, pri čemu ne treba utvrđivati i da su oni stvarno doveli do održanja stvari. ${ }^{33}$ Korisni troškovi su oni kojima se povećava vrijednost stvari. ${ }^{34}$ Je li došlo do povećanja vrijednosti stvari također se procjenjuje u svakom konkretnom slučaju po objektivnom kriteriju (tržnom), što znači da nije bitan subjektivni stav vlasnika stvari prema povećanju vrijednosti stvari (osim kod promjene namjene stvari).

U svojoj osnovi potraživanje naknade nužnih i korisnih troškova poštenog posjednika obveznopravni je zahtjev temeljem stjecanja bez osnove vlasnika stvari, ${ }^{35}$ s time da su odredbe ZV-a lex specialis u odnosu na odredbe ZOO-a, odnosno odredbe ZOO-a supsidijarno se primjenjuju na ono što nije regulirano u ZV-u. Kod izračunavanja visine nužnih i korisnih troškova koje osnovano potražuje pošteni posjednik, njemu će se odbiti vrijednost plodova i drugih koristi koje je imao od stvari. ${ }^{36}$ Ako pošteni posjednik ne traži naknadu nužnih i korisnih troškova, vlasnik ne može od njega potraživati vrijednost plodova i drugih koristi koje je pošteni posjednik imao za vrijeme poštenog posjeda stvari. Ako traži naknadu nužnih i korisnih troškova ta vrijednost i koristi uzimaju se u obzir i oduzimaju se od vrijednosti troškova koje pošteni posjednik osnovano traži. Smatramo da je takvo rješenje pravično, jer ne bi bilo prihvatljivo da pošteni posjednik zadrži sve plodove i koristi od stvari, a s druge strane, da od vlasnika ima pravo zahtijevati nužne i korisne troškove jer bi time imao više prava nego da je sam vlasnik stvari. Nadalje, ZV propisuje da se troškovi i vrijednost plodova obračunavaju prema cijenama kad ih se naknađuje, što je suprotno ranijoj sudskoj praksi u svezi s primjenom odredbi čl. 38. ZOVO-a koji to nije regulirao i prema kojoj se obračun vršio prema cijenama kada su učinjeni troškovi. ${ }^{37}$

32 Klarić i Vedriš, op. cit. str. 298. Gavella nužne troškove definira kao one bez kojih bi stvar propala, pogoršala se ili bi joj se smanjila vrijednost (Gavella, op. cit. str. 605.).

33 Tako je zaključeno da su nužni troškovi poštenog posjednika oni koje je on imao da bi kuću koja mu je dodijeljena na privremeno korištenje osposobio za stanovanje (odluka VSRH broj Rev-764/2008 od 12. rujna 2012., htpps://sudskapraksa.csp.vsrh.hr, očitanje 2. veljače 2017.) ili da bi se poslovni prostor osposobio za namjenu za koju je dan u zakup (odluka VSRH broj Rev-1029/05 od 4. svibnja 2006. htpps://sudskapraksa.csp.vsrh.hr, očitanje 2. veljače 2017.).

34 Klarić i Vedriš, op. cit. str. 299.

35 V. čl. 1111. ZOO-a i infra pogl. 5. O tome v. odluku VSRH broj Rev-1029/05 od 4. svibnja 2006., htpps://sudskapraksa.csp.vsrh.hr, očitanje 2. veljače 2017., u kojoj se navodi: Odlučujući o pravu tužitelju na povrat uloženih sredstava, odnosno nužne i korisne troškove sudovi su se pravilno pozvali na čl. 210. st. 1. Zakona o obveznim odnosima prema kojoj kad dio imovine jedne osobe na bilo koji način prijeđe u imovinu druge osobe, a taj prijelaz nema osnove na nekom pravnom poslu ili zakonu, stjecalac je dužan vrati ga ako je to moguće, a inače je dužan nadoknaditi vrijednost postignute koristi. Pripada li pravo na naknadu onome tko je ulagao u kakvu (tuđu) zgradu ili prostoriju (dogradnja, nadogradnja, preuređenje zgrade ili prostorije) određuju pravila stvarnog prava (čl. 156. st. 2. Zakona o vlasništvu i drugim stvarnim pravima).

36 V. čl. 164. st. 5. ZV.

37 V. odluku VSRH broj Rev-252/97 od 23. studenog 2000., htpps://sudskapraksa.csp.vsrh.hr, očitanje 2. veljače 2017. u kojoj je izraženo sljedeće pravno stajalište: "Spomenuta naknada 


\subsection{Pravo zadržanja stvari poštenog posjednika}

Pošteni posjednik od kojeg je vlasnik stvari zatražio predaju stvari, i koji je zatražio od vlasnika stvari naknadu za nužne i korisne troškove koje je imao tijekom posjedovanja stvari, ima pravo zadržati stvar dok mu oni ne budu naknađeni. ${ }^{38}$ Dakle, daljnje pravo poštenog posjednika prema vlasniku stvari pravo je zadržanja (ius retentionis). Podredno će se na pravo retencije primjenjivati propisi obveznog prava. ${ }^{39}$ U svezi prava zadržanja postoji opsežna sudska praksa, pa tako i najvišeg suda u RH. Tako je pravno stajalište VSRH da su odredbe ZV-a o pravu zadržanja lex specialis u odnosu na odredbe ZOO-a, te da nema mogućnosti prihvatiti zahtjev za predaju stvari u posjed vlasniku, ako je osnovano i pravo zadržanja poštenog posjednika. ${ }^{40}$ Pravo zadržanja može se ostvariti i u odnosu na nekretnine, a ne samo u odnosu na pokretnine. ${ }^{41} \mathrm{~S}$ postupovnopravnog aspekta pravo zadržanja akcesorno je pravo ovisno o dospjelom i utuženom potraživanju za naknadu nužnih i korisnih troškova, slijedom čega se pošteni posjednik na pravo zadržanja može pozvati i prigovorom. ${ }^{42}$ Ako se

učinjenih troškova pripada savjesnom posjedniku u smislu odredbe čl. 223. Zakona o obveznim odnosim, međutim naknada nužnih i korisnih troškova u odnosu na visinu se u takvom slučaju utvrđuje prema cijenama u vrijeme kada su ti troškovi ostvareni odnosno kada su ti izdaci učinjeni".

38 V. čl. 164. st. 2. ZV.

39 V. čl. 72. - 75. ZOO. Tako primjerice pošteni posjednik stvari temeljem odredbe čl. 73. st. 2. ZOO-a nema pravo zadržanja stvari koje se ne mogu izložiti prodaji ili u smislu odredbe čl. 74. ZOO-a pošteni posjednik nema pravo zadržanja stvari ako mu vlasnik stvari pruži osiguranje za njegovo potraživanje naknade nužnih i korisnih troškova.

40 V. odluke VSRH broj Rev-1930/12 od 12. ožujka 2014. i broj Revx-181/11 od 19. siječnja 2012., htpps://sudskapraksa.csp.vsrh.hr, očitanje 3. veljače 2017. Da su odredbe ZV-a lex specialis u odnosu na odredbe ZOO-a proizlazi iz odluke VSRH broj Rev-1930/12 u kojoj se navodi: "U slučaju kada vlasnik potražuje stvar, a što je slučaj u ovom predmetu, a posjednik tj. tuženica zahtijeva naknadu troškova ulaganja, tada se primjenjuju odredbe ZVDSP kao lex specialis u odnosu na odredbe Zakona o obveznim odnosima ("Narodne novine" br. 35/05, 41/08, dalje ZOO) o pravu retencije (čl. 72. do 75.)". Kod osnovanog zahtjeva za zadržanje stvari, sud može prihvatiti zahtjev za predaju stvari samo pod uvjetom da vlasnik prije toga isplati poštenom posjedniku naknadu za nužne i korisne troškove jer pravo zadržanja stvari u svojoj osnovi isključuje i pravo vlasnika da mu se preda stvar u posjed (tako i u odluci VSRH broj Rev-154/08 od 18. studenog 2009., htpps://sudskapraksa.csp.vsrh.hr, očitanje 2. veljače 2017.).

41 V. odluku VSRH broj Rev-933/00 od 29. siječnja 2002., htpps://sudskapraksa.csp.vsrh.hr, očitanje 3. veljače 2017. u kojoj je zauzeto sljedeće pravno stajalište: Pogrešno nižestupanjski sudovi smatraju da se pravo retencije veže samo uz držanje pokretne stvari. Naime, prema odredbi čl. 286. st. 1. Zakona o obveznim odnosima vjerovnik dospjelog potraživanja u čijim se rukama nalazi neka dužnikova stvar ima pravo zadržati je dok mu ne bude isplaćeno potraživanje. Kako tom zakonskom odredbom pravo zadržanja nije ograničeno samo na držanje pokretnih stvari, valja zaključiti da se pravo zadržanja može vršiti i uz držanje dužnikove nekretnine.

42 V. odluku VSRH broj Rev-695/1999 od 30. listopada 2002., htpps://sudskapraksa.csp.vsrh.hr, očitanje 3. veljače 2017. u kojoj je navedeno: Pravo zadržanja, u biti, ima suprotstavljajući značaj, kao preventivno sredstvo zaštite dospjelog potraživanje kojeg posjednik stvari ima prema dužniku, odnosno čin pritiska na dužnika da ispuni svoju obvezu prema posjedniku stvari. To pravo je vremenski neograničeno. Tek za slučaj da posjednik stvari svoje potraživanje želi namiriti iz zadržane stvari, treba ustati (protu)tužbom, kako bi, radi namirenja tog 
pošteni posjednik suprotstavio vindikacijskom zahtjevu osnovanim prigovorom prava zadržanja stvari na ime naknade nužnih i korisnih troškova, on će uspjeti zaustaviti predaju u posjed, ali se neće moći naplatiti na ime svojeg potraživanja ako nije postavio protutužbeni zahtjev, koji mu usvojen od suda može biti jedino osnova za naplatu potraživanja iz zadržane stvari. ${ }^{43}$ Ako je između vlasnika stvari i poštenog posjednika sklopljen određeni ugovor koji je osnova posjedovanja stvari poštenog posjednika, i ako je u tom pravnom poslu reguliran međusobni odnos na ime ulaganja i troškova u svezi s posjedovanjem stvari, ne dolazi do primjene odredba čl. 164. st. 2. ZV-a u svezi s pravom na naknadu nužnih i korisnih troškova te prava zadržanja, već se primjenjuju odredbe iz ugovora sukladno volji stranaka i postojećem obveznopravnom odnosu. ${ }^{44}$ Ne može se ostvariti pravo zadržanja na poslovnom prostoru koji nije samostalna cjelina (nije provedeno etažiranje) jer se ne radi o stvari koja može biti samostalno u prometu. ${ }^{45}$

potraživanja, ishodio ovršni naslov. Stajalište je, dakle, ovog suda da se pošteni posjednik stvari, zahtjevu vlasnika za predaju stvari, prema kojem posjednik ima dospjelo potraživanje, može osnovano suprotstaviti i prigovorom kao procesnom radnjom, da će stvar zadržati sve dok mu protustranka u cijelosti ne podmiri njegovo potraživanje, koje, kako je navedeno treba biti određeno postavljeno.

43 Ibid.

44 V. odluke VSRH broj Rev-266/07 od 5. prosinca 2007., broj Rev-493/11 od 29. listopada 2013. i broj Rev-3258/94 od 22. siječnja 1998., htpps://sudskapraksa.csp.vsrh.hr, očitanje 3. veljače 2017. Tako je u odluci VSRH broj 493/11 navedeno: Međutim, obzirom je ovdje riječ o obveznopravnom odnosu stranaka koji je reguliran odredbama ZZPPP-a kojima (iz čl. 11 . $i$ drugima) nije predviđena mogućnost prava zadržanja poslovnog prostora radi osiguranja namirenja uloženih sredstava, ali i obveznopravnom odnosu nastalom ugovorom o zakupu poslovnog prostora glede prava na naknadu troškova ulaganja u poslovni prostor kojim su (pravom) stranke ugovora mogle slobodno raspolagati - $i$ (ovdje odlučno) raspolagale tako što je tuženik kao zakupnik uzeo u zakup poslovni prostor u viđenom stanju i ujedno u svezi s time izrazio suglasnost da to pravo (na povrat sredstava uloženih u uređenje poslovnog prostora) nema $i$ da će troškove uređenja prostora snositi sam, tuženik, kojeg vežu odredbe ugovora $i$ dužan je poštivati ono što je ugovorio, ne može sada s uspjehom zahtijevati ono što je ugovorom izričito i nedvosmisleno otklonio - naknadu uloženog u zakupljeni prostor, slijedom čega nema niti pravo na kojemu ustraje i koje se (prema odredbama čl. 164. st. 2. ZV-a i čl. 72. st. 1. ZOO-a) može ostvariti samo uz pretpostavku postojanja prava na naknadu uloženog: pravo da zadrži poslovni prostor dok mu naknada ne bude isplaćena.

45 V. odluku broj Rev-2907/91 od 25. ožujka 1992., htpps://sudskapraksa.csp.vsrh.hr, očitanje 3. veljače 2017. u kojoj je navedeno: Na kraju valja reći da tuženik neosnovano ističe da ima pravo zadržanja - zadržati u posjedu poslovnu prostoriju tužitelja dok mu ovaj ne plati naknadu za uložena sredstva. Ovo zbog toga, što nije, kako je utvrdjeno, ispunjena pretpostavka predviđena u odredbi čl. 287. st. 2. ZOO, jer se predmetna poslovna prostorija nalazi u sastavu kuće gdje ne postoji zasnovano etažno vlasništvo, pa se poslovna prostorija sama za sebe ne može zaplijeniti i izvrgnuti prodaji. 


\subsection{Zastara prava poštenog posjednika na naknadu nužnih i korisnih troškova}

ZV propisuje da pravo poštenog posjednika na naknadu nužnih i korisnih troškova zastarijeva u roku od tri godine od dana predaje stvarii ${ }^{46} \mathrm{~S}$ obzirom na takvu odredbu ZV-a moglo bi se zaključiti da danom predaje u posjed stvari dospijeva i potraživanje naknade nužnih i korisnih troškova poštenog posjednika prema vlasniku stvari, odnosno da bi podnošenje zahtijeva za naknadu nužnih i korisnih troškova prije predaje stvari bilo preuranjeno. Naime, opća odredba u čl. 215. st. 1. ZOO-a o tome kad zastara počinje teći određuje da je to prvog dana kad je vjerovnik imao pravo zahtijevati ispunjenje obveze, osim ako zakonom za pojedine slučajeve nije što drugo propisano. Upravo u slučaju potraživanja naknade nužnih i korisnih troškova poštenog posjednika od vlasnika stvari, postoji iznimka od općeg pravila o dospijeću obveze, jer to proizlazi iz odredbe čl. 164. st. 2. ZV-a. Kod prava poštenog posjednika na potraživanje naknade nužnih i korisnih troškova razlikuju se trenutak dospijeća tražbine i trenutak od kojeg počinje teći zastara, s obzirom na to da pošteni posjednik može već u postupku povodom vlasničke tužbe istaknuti zahtjev za naknadu nužnih i korisnih troškova, a povrh toga i zadržati stvar dok mu ti troškovi ne budu naknađeni. ${ }^{47}$ Stoga se zahtjev za naknadu nužnih i korisnih troškova može postaviti i prije nego što uopće zastara počne teći, a jedini je preduvjet da vlasnik zahtijeva predaju stvari. ${ }^{48}$

Ako je do predaje stvari došlo prije nego što je pošteni posjednik zahtijevao naknadu nužnih i korisnih troškova, on neće moći ostvariti pravo zadržanja stvari, a protekom tri godine od predaje stvari zastarit će mu i sam zahtjev za naknadu nužnih i korisnih troškova. Posebno je bitno istaknuti da ako nema pretpostavki za primjenu čl. 164. st. 2. ZV-a (jer vlasnik uopće ne zahtijeva predaju stvari), postoji mogućnost potraživanja poštenog posjednika stvari naknade nužnih i korisnih troškova temeljem instituta sjecanja bez osnove ili temeljem ugovornog odnosa koji je osnova prava na posjed, i u kojem slučaju se primjenjuje opći zastrani rok od pet godina ${ }^{49}$ Kod pitanja

46 V. čl. 164. st. 7. ZV.

47 Pravo zadržanja stvari poštenog posjednika radi osiguranja naknade nužnih i korisnih troškova od vlasnika koji traži predaju stvari bilo bi bez ikakva smisla kad bi se tumačilo da pošteni posjednik može staviti zahtjev za naknadu tih troškova tek nakon što je stvar predao vlasniku.

48 Ako vlasnik ne zahtijeva predaju stvari nema uopće mjesta primjeni odredbi čl. 164. st. 2. - 7 . $\mathrm{ZV}$.

49 V. čl. 225. ZOO. O tome v. odluke VSRH broj Revx-294/14 od 15. travnja 2015. i broj Revx358/11 od 20. studenog 2013., htpps://sudskapraksa.csp.vsrh.hr, očitanje 3. veljače 2017. U odluci broj Revx-358/11 je navedeno: Međutim, zastara potraživanja za stjecanje bez osnove do kojeg je došlo ulaganjem tuđeg rada i sredstava u nekretnine tuženika (čl. 215. u svezi s odredbom čl. 210. ZOO-a) počinje teći od dana kada je neosnovano obogaćeni stekao mogućnost ubirati korist od izvršenih ulaganja (koju činjenicu, vrijeme kada su tužitelji predmetnu nekretninu predali tuženicima, su nižestupanjski sudovi propustili utvrditi), a ne kako to pogrešno cijeni drugostupanjski sud, od dana kada su ta ulaganja učinjena. Početak tijeka zastare jednako je uređen i odredbom čl. 164. st. 7. Zakona o vlasništvu i drugim stvarnim pravima), jer pravo na naknadu nužnih i korisnih troškova zastarijeva od dana predaje stvari, $s$ time da se u pretpostavkama iz odredbe čl. 164. ZV-a radi o trogodišnjem, a ne općem zastarnom roku, koji se primjenjuje u konkretnom slučaju. 
zastare prava poštenog posjednika potraživati naknadu nužnih i korisnih troškova, postavlja se pitanje bi li protekom zastarnog roka od tri godine pošteni posjednik mogao potraživati istu naknadu temeljem instituta stjecanja bez osnove, ako mu nije istekao opći zastarni rok od pet godina. Mišljenja sam da to nije moguće, jer bi se time odredba čl. 164. st. 7. ZV-a o zastari kao lex specialis u potpunosti stavila izvan snage. U sudskoj se praksi potraživanja naknade ulaganja u tuđu stvar, pa tako i potraživanja nužnih i korisnih troškova poštenog posjednika, vrlo često pravno kvalificiraju kao stjecanje bez osnove vlasnika stvari ili čak poslovodstvo bez naloga i sl..$^{50} \mathrm{O}$ pretpostavkama i razgraničenju u primjeni odredbi ZV-a i ZOO-a u svezi s postavljanjem zahtjeva za naknadu nužnih i korisnih troškova poštenog posjednika, bit će više riječi u poglavlju koje će detaljnije obrađivati taj odnos i gdje će biti zauzeta određena stajališta. O zastari potraživanja naknade nužnih i korisnih troškova VSRH je u nizu svojih odluka zauzeo stajališta s obzirom na konkretne okolnosti slučaja, o tome je li u konkretnom slučaju došlo do zastare potraživanja ili ne. ${ }^{51}$

\subsection{Pravo poštenog posjednika na odvajanje i odnošenje dodanog stvari}

Pošteni posjednik nema pravo zahtijevati naknadu troškova koji nisu nužni i korisni, odnosno nema pravo na naknadu tzv. luksuznih troškova koje je učinio radi

50 V. primjerice odluku VSRH broj 22/07 od 4. travnja 2007., htpps://sudskapraksa.csp.vsrh.hr, očitanje 3. veljače 2017., gdje je prihvaćeno da se radi o stjecanju bez osnove jer je temeljem tog instituta obveznog prava postavljen zahtjev.

51 V. primjerice odluke VSRH broj Revx-358/11 od 20. studenog 2013., broj Revx-1079/10 od 23 veljače 2011., broj Gzz-162/04 od 30. ožujka 2005., broj Rev-610/06 od 15. studenog 2006, broj Rev-22/07 od 4. travnja 2007. i broj Revx-294/14 od 15. travnja 2015., htpps://sudskapraksa. csp.vsrh.hr, očitanje 4. veljače 2017. Tako je u odluci broj Revx-1079/10 VSRH zaključio: Ocjenjujući pitanje zastare sudovi su zaključili da potraživanje tužitelja zastarijeva u roku od tri godine prema odredbi čl. 164. st. 7. Zakona o vlasništvu i drugim stvarnim pravima, a ne u roku od pet godina u kojem zastarijevaju tražbine koje se temelje na pravnoj osnovi stjecanja bez osnove. Suprotno revizijskim navodima pitanje zastare sudovi su pravilno ocijenili, pa je materijalno pravo pravilno primijenjeno kada je zbog zastare tužbeni zahtjev odbijen kao neosnovan”. Nadalje, u odluci VSRH broj Rev-610/06 sud je naveo sljedeće: Odlučujući o zahtjevu sud prvog stupnja nadalje propustio je utvrditi pravni osnovu protutužbenog zahtjeva. Doduše se u razlozima presude pozvao na institut naknade štete, iako bi se moglo raditi o stjecanju bez osnove do kojeg je došlo ulaganjem tuđeg rada i sredstava u smislu čl. 215. u vezi čl. 210. Zakona o obveznim odnosima ("Narodne novine", broj 53/91, 79/91, 3/94, 7/96, 112/99 i 88/01 - dalje: ZOO), odnosno o zahtjevu za naknadu nužnih i korisnih troškova koje je tuženik imao prema odredbi čl. 164. st. 2. Zakona o vlasništvu i drugim stvarnim pravima ("Narodne novine", broj 91/96, 68/98, 137/99, 12/00, 73/00 i 114/01-dalje: ZV) ili čl. 38. bivšeg Zakona o osnovnim vlasničkopravnim odnosima ("Narodne novine”, broj 53/91, 9/92 i 77/92 - dalje: ZOVO) ovisno koji zakon treba primijeniti. Zastara potraživanja iz stjecanja bez osnove do kojeg je došlo ulaganjem tuđeg rada i sredstava u poslovni prostor tužitelja, počinje teći od dana kada je neosnovano obogaćeni stekao mogućnost da ubire koristi od izvršenih ulaganja, što nije utvrđeno, jer nije razjašnjeno kada je predmetni poslovni prostor predan tužitelju. Početak tijeka zastare jednako je uređen i odredbom čl. 164. st. 7. ZV, jer pravo na naknadu nužnih i korisnih troškova zastarijeva od dana predaje stvari, s time da se prema tom propisu radi o trogodišnjem, a ne općem zastarnom roku od pet godina iz čl. 371. ZOO, koji je u primjeni kod instituta stjecanja bez osnove. 
svojeg zadovoljstva, uljepšavanja stvari, veće udobnosti i sl. ${ }^{52} \mathrm{U}$ takvom slučaju pošteni posjednik može prije nego što je stvar vratio vlasniku odvojiti i sebi uzeti ono što je stvari dodao tim troškovima pod uvjetom da to može učiniti bez oštećenja stvari. ${ }^{53}$ Stoga su pretpostavke za korištenje prava odnošenja (ius tollendi): da se ne radi o nužnim i korisnim troškovima već o tzv. luksuznim troškovima (impensae voluptuariae), da poštenom posjedniku vlasnik nije ponudio naknadu za te troškove, da je stvar još uvijek u posjedu poštenog posjednika i da odvajanje dodanog stvari pošteni posjednik može učiniti bez oštećenja stvari. O tomu radi li se o nužnim i korisnim troškovima ili tzv. luksuznim troškovima, procjenjuje se u svakom konkretnom slučaju s obzirom na konkretne okolnosti. ${ }^{54}$

\section{PRAVA I OBVEZE NEPOŠTENOG POSJEDNIKA PREMA VLASNIKU STVARI}

U čl. 165. ZV-a reguliran je pravni položaj nepoštenog posjednika koji nema pravo posjedovati vlasnikovu stvar i koji je mora predati vlasniku ili osobi koju vlasnik odredi. Nepošteni posjednik u taj pravni položaj može doći nakon što je obvezan stvar vratiti vlasniku na temelju vindikacijskog zahtjeva i nakon što je stavio svoje protuzahtjeve u odnosu na troškove koje je imao tijekom poštenog posjeda stvari. Isto tako nepošteni posjednik $u$ isti položaj dolazi i ako je spreman dobrovoljno vratiti stvar vlasniku, ali nije postignut sporazum s vlasnikom stvari o naknadi troškova. Za razliku od poštenog posjednika, pravni položaj nepoštenog posjednika daleko je nepovoljniji, odnosno nepošteni obveznik ima veće obveze, a manja prava u odnosu na vlasnika stvari. Obveza nepoštenog posjednika stvari prema vlasniku stvari je da istu preda vlasniku ili osobi koju odredi vlasnik te da naknadi sve štete koje su nastale na stvari, kao i sve koristi koje je nepošteni posjednik imao za vrijeme posjedovanja stvari, uključujući i one koje bi stvar dala da ih nije zanemario. ${ }^{55} \mathrm{~S}$ druge strane, nepošteni posjednik ima pravo na naknadu samo nužnih troškova ako bi oni bili nužni i vlasniku, ali za te troškove nema pravo zadržanja stvari, već stvar vlasniku mora predati bez odgode. ${ }^{56}$ Nepoštenom posjedniku također se ne naknađuju tzv. luksuzni troškovi, a on ima pravo odnošenja dodanog stvari za one troškove koji mu se ne naknađuju.

52 V. čl. 164. st. 4. ZV.

53 Ibid.

54 O tome v. odluke VSRH broj Rev-194/91 od 24. travnja 1991., broj Rev-1578/94 od 9. veljače 1999. i broj Revx-517/11 od 17. veljače 2015., htpps://sudskapraksa.csp.vsrh.hr, očitanje 4. veljače 2017. Tako je u odluci VSRH broj Revx-517/11, prihvaćeno stajalište nižestupanjskih sudova u odnosu na protutužbeni zahtjev da tuženiku ne pripada pravo na naknadu troškova postavljanja alarmnog uređaja i ukrasnih greda na stropu jer se radi o luksuznim troškovima.

55 V. čl. 165. st. 1. ZV.

56 V. čl. 165. st. 3. i 4. ZV. 


\subsection{Obveze nepoštenog posjednika prema vlasniku stvari}

Osnovna obveza nepoštenog posjednika stvari je da vlasniku ili osobi koju on odredi preda stvar. Daljnje obveze nepoštenog posjednika su da na zahtjev vlasnika stvari istome naknadi sve štete koje su na stvari nastale za vrijeme njegova posjedovanja te da naknadi sve koristi koje je imao za vrijeme posjedovanja stvari, uključujući i one koje bi stvar dala da ih nije zanemario. ${ }^{57}$ Za razliku od poštenog posjednika koji je obvezan samo predati stvar vlasniku na njegov zahtjev, ${ }^{58}$ nepošteni posjednik dužan je vlasniku predati sve koristi koje je imao od stvari ili ako to nije moguće dati naknadu za te koristi. ${ }^{59}$ Tako je nepošteni posjednik koji je koristio poslovni prostor bez prava na posjed, dužan vlasniku na ime naknade koristi koje je imao za vrijeme korištenja poslovnog prostora, dati naknadu najmanje u visini zakupnine koju je plaćao ili koja se prosječno plaća za takav prostor. ${ }^{60}$ Potraživanje vlasnika stvari na ime naknade štete ili naknade za koristi od stvari zastarijeva u roku od tri godine od dana kad je posjednik predao stvar vlasniku. ${ }^{61}$ Sve ono što je navedeno za zastaru i dospijeće potraživanja poštenog posjednika na ime nužnih i korisnih troškova prema vlasniku stvari, vrijedi i kod zastare potraživanja vlasnika prema nepoštenom posjedniku na ime eventualne štete na stvari ili na ime naknade za koristi koje je imao pošteni posjednik. ${ }^{62}$

\subsection{Prava nepoštenog posjednika prema vlasniku stvari}

Nepošteni posjednik može od vlasnika stvari kojem mora predati stvar zahtijevati samo naknadu nužnih troškova koje je imao za vrijeme dok je imao u posjedu stvar. Nepošteni posjednik je i u pogledu tog prava u lošijem položaju od poštenog posjednika jer nema pravo na naknadu nužnih troškova prema objektivnom kriteriju,

57 V. supra bilj. 56.

58 Uz iznimku za one koristi koje ne bi bile primjerene pravu na posjed za koji je pošteni posjednik vjerovao da mu pripada. V. supra bilj. 28.

59 To se odnosi na sve već odvojene i iskorištene plodove, postojeće plodove i koristi od uporabe. Također se to odnosi na zanemarene koristi, odnosno one koristi koje je nepošteni posjednik propustio ostvariti.

60 Odluke VSRH broj Rev-54/09 od 15. travnja 2009., broj Revx-942/14 od 11. veljače 2015., broj Revx-765/14 od 11. studenog 2014., broj Revx-1233/13 od 1. travnja 2014., broj Revx573/12 od 25. veljače 2014. i broj Revx-362/14 od 28. svibnja 2014., htpps://sudskapraksa. csp.vsrh.hr, očitanje 4. veljače 2017. Tako se u odluci VSRH broj Rev-54/09 navodi: Prema odredbi čl. 165. st. 1. Zakona o vlasnišstvu i drugim stvarnim pravima nepošteni posjednik tuđe stvari mora je predati vlasniku ili osobi koju taj odredi, te naknaditi sve štete koje su na njoj nastale i sve koristi koje je imao za vrijeme svojeg posjedovanja, pa i one koje bi stvar dala da ih nije zanemario. Obavljanjem ugostiteljske djelatnosti tužitelj je u poslovnom prostoru tuženika ostvarivao određene koristi, jer u slučaju da je koristio neki drugi poslovni prostor za istu svrhu bio bi dužan plaćati zakupninu za korištenje poslovnog prostora. U odluci broj Revx-942/14 se navodi sljedeće: Naime, pravilno je shvaćanje nižestupanjskih sudova da je tuženica u utuženom razdoblju od predmetne nekretnine stekla koristi bar za iznos zakupnine koju bi inače trebala plaćati, čime takva korist koju je imala od korištenja poslovnog prostora predstavlja iznos koji je u smislu odredbe čl. 165. st. 1. ZV-a dužna platiti tužitelju.

61 V. čl. 165. st. 2. ZV.

62 V. supra pogl. 3.4. prvi odlomak. 
već po subjektivnom kriteriju, što znači samo onih koji bi bili nužni i vlasniku. ${ }^{63} \mathrm{Za}$ razliku od poštenog posjednika, nepošteni posjednik nema pravo na naknadu korisnih troškova uopće ${ }^{64}$ te isto kao pošteni posjednik, nema pravo na naknadu tzv. luksuznih troškova. Nepošteni posjednik ima također pravo na odvajanje i odnošenje onog što je dodao stvari, ako to može učiniti bez oštećenja stvari. ${ }^{65}$ Međutim, nepošteni posjednik ima pravo odvajanja i odnošenja dodanog stvari, ako je to moguće, u pogledu svih troškova koji mu se ne naknađuju, a ne samo luksuznih. ${ }^{66} \mathrm{Na}$ kraju, nepošteni posjednik nema pravo retencije stvari za osiguranje zatražene naknade nužnih troškova i dužan je stvar bez odgađanja predati vlasniku.

Nepošteni posjednik ukupno ima daleko manje prava od poštenog posjednika te tako nepošteni posjednik nema pravo na naknadu korisnih troškova uopće, nema pravo na naknadu svih nužnih troškova i nema pravo retencije. Jedino ima veća prava od poštenog posjednika u pogledu prava odvajanja i odnošenja poboljšica, ali će to pravo u praksi biti najčešće teško provedivo zbog mogućnosti oštećenja stvari. Rokovi zastare i dospijeća potraživanja naknade nužnih troškova identični su kao i kod poštenog posjednika te sve što je navedeno kod zastare potraživanja naknade nužnih i korisnih troškova poštenog posjednika, vrijedi i za potraživanje naknade nužnih troškova nepoštenog posjednika.

\section{ODNOS I PRIMJENA PROPISA OBVEZNOG PRAVA PREMA PROPISIMA STVARNOG PRAVA}

Već je navedeno da se za pravni položaj poštenog i nepoštenog posjednika prema vlasniku stvari u dijelu gdje se potražuju naknade za ulaganja i učinjene troškove i pravo zadržanja, primjenjuju podredno propisi obveznog prava, prije svega oni koji reguliraju stjecanje bez osnove. Odredbe $\mathrm{ZV}$-a su lex specialis te se one primjenjuju primarno, a odredbe ZOO-a samo ako to nije regulirano u ZV-u. To je razgraničenje vrlo bitno jer je primjerice zastara potraživanja temeljem stjecanja bez osnove u općem zastarnom roku od pet godina, dok je prema ZV-u zastara potraživanja vlasnika stvari i posjednika stvari u roku od tri godine. ${ }^{67}$ Nadalje, zbog sličnosti odredbi ZV-a koje reguliraju prava i obveze posjednika prema vlasniku stvari s odredbama obveznog prava koje reguliraju institut sjecanja bez osnove, u praksi sudova vrlo često dolazi

63 To znači da ako se u postupku utvrdi, da neki objektivno potreban nužni trošak vlasnik ne bi napravio da je stvar bila u njegovu posjedu, nepoštenom posjedniku neće pripadati takav trošak. To će u praksi biti rjeđi slučaj, ali je moguće da vlasnik za neki nužan trošak po objektivnom kriteriju dokazuje da ga on ne bi imao.

64 Prema čl. 39. st. 5. ZOVO-a nepošteni posjednik imao je pravo i na naknadu korisnih troškova pod istim uvjetima kao i za nužne troškove - ako su bili korisni osobno za vlasnika. ZV je očigledno još više smanjio prava nepoštenog posjednika, pri čemu smatramo da je rješenje iz ZOVO-a bilo prihvatljivije. To jer bi nepošteni posjednik mogao imati znatna ulaganja u stvar koja bi predstavljala objektivno i veliko povećanje vrijednosti stvari te ako bi i sam vlasnik učinio takva ulaganja, smatramo da je pravednije rješenje iz ZOVO-a.

65 V. čl. 165. st. 5. ZV.

66 Ius tollendi kod nepoštenog posjednika obuhvaćao bi nužne troškove koji nisu bili nužni za vlasnika te sve korisne i luksuzne troškove koje je ima nepošteni posjednik.

67 V. čl. 215. st. 1. ZOO i čl. 164. st. 7. i čl. 165. st. 2. i 3. ZV. 
do pogrešne primjene materijalnog prava, odnosno do miješanja tih pravnih instituta obveznog i stvarnog prava. ${ }^{68}$

Da bi došlo do primjene odredbi čl. 164. i 165. ZV, potraživanja se moraju temeljiti na ulaganjima i troškovima koje je posjednik imao za vrijeme posjedovanja vlasnikove stvari. Ako je netko ulagao u stvar ili za nju imao troškove, a koja nikad nije bila u njegovu posjedu, nema mjesta primjeni odredbi ZV-a. Tada se može govoriti isključivo o stjecanju bez osnove ili eventualno poslovodstvu bez naloga. ${ }^{69}$ Nadalje, nema mjesta primjeni odredbi čl. 164. i 165. ZV-a kada vlasnik ne zahtijeva predaju stvari niti je posjednik dobrovoljno sam predao stvar vlasniku. To se odnosi na situaciju kada posjednik i dalje nesmetano ima u posjedu stvar, a potražuje naknadu za izvršena ulaganja u stvar. ${ }^{70}$ Također nema primjene odredbi stvarnog prava koje reguliraju pravni položaj poštenog i nepoštenog posjednika iako su za to ispunjene pretpostavke iz ZV-a, ako je između posjednika i vlasnika stvari sklopljen pravni posao koji drukčije regulira ta prava. ${ }^{71}$

Kod prava zadržanja stvari poštenog posjednika radi osiguranja potraživanja naknade nužnih i korisnih troškova, odredba čl. 164. st. 2. ZV-a je lex specialis u odnosu na opću odredbu ZOO-a o pravu zadržanja. ${ }^{72}$ Tako prema općoj odredbi o pravu zadržanja iz ZOO-a, vjerovnik dospjele tražbine može zadržati bilo koju stvar koju drži u rukama dok mu ne bude ispunjena tražbina. Pravo retencije iz ZV-a odnosi se samo na stvar u odnosu na koju je pošteni posjednik imao troškove te on ne može zadržati kao osiguranje bilo koju stvar vlasnika koju bi eventualno držao u svom posjedu, već samo onu u odnosu na koju potražuje naknadu troškova. ${ }^{73}$ Pravo

68 Tako se u odluci VSRH broj 1029/05 od 4. svibnja 2006. navodi: Sudovi zaključuju da tužitelj kao pošteni posjednik ima pravo zahtijevati naknadu uloženih sredstava, odnosno naknadu za nužne i korisne troškove koje je imao da bi navedeni poslovni prostor priveo ugovorenoj namjeni za obavljanje ugostiteljske djelatnosti kojom se tužitelj bavio. Odlučujući o pravu na povrat uloženih sredstava, odnosno nužne i korisne troškove, sudovi su se pravilno pozvali na čl. 210. Zakona o obveznim odnosima ("Narodne novine", broj 53/91, 73/91, 3/94, 7/96 i 112/99 - dalje ZOO/91) prema kojoj kad dio imovine jedne osobe na bilo koji način prijeđe u imovinu druge osobe, a taj prijelaz nema osnove na nekom pravnom poslu ili zakonu, stjecalac je dužan vratiti ga ako je to moguće, a inače je dužan nadoknaditi postignute korist. Kasnije se u odluci zaključuje da tužitelj ima pravo na nužne i korisne troškove uz pravilnu primjenu odredbi ZV i ZOO/91.

69 O poslovodstvu bez naloga v. odluke VSRH broj Rev-421/10 od 20. ožujka 2012. i broj Rev1063/07 od 18. veljače 2010.

70 On se tada neće moći s uspjehom pozvati niti na stjecanje bez osnove, jer prema usvojenoj sudskoj praksi zahtjev za naknadu stečenog bez osnove dospijeva tek u trenutku kad je stjecatelj stekao mogućnost ubirati korist od izvršenih ulaganja, a to je opet kad je stvar predana vlasniku ili stjecatelju, a ne kad su ulaganja vršena.

71 Npr. temeljem ugovora o zakupu kojim je izričito zabranjeno ulaganje posjednika u stvar bez pristanka vlasnika.

72 V. čl. 75. st. 1. ZOO.

73 V. odluku VSRH broj II Rev-80/90 od 5. prosinca 1990., htpps://sudskapraksa.csp.vsrh.hr, očitanje 4. veljače 2017. U navedenoj odluci se u svezi s pravom zadržanja poštenog posjednika navodi: Odredba čl. 38. st. 7. Zakona o osnovnim vlasničkopravnim odnosima odnosi se na osiguranje tražbine proistekle iz troškova održavanja. Stvari, a predmetno tuženikovo (prodavateljevo) potraživanje se ne odnosi na takve troškove. 
zadržanja poštenog posjednika prema odredbi čl. 164. st. 2. ZV-a i kod ispunjenja svih pretpostavki ipak neće pripadati poštenom posjedniku ako je to pravo drukčije regulirano pravnim poslom između stranaka. ${ }^{74}$

Stoga kod odnosa i primjene propisa stvarnog ili obveznog prava za prava i obveze posjednika stvari prema vlasniku, treba prvotno poći od njihova eventualno postojećeg pravnog posla koji regulira ta prava i obveze, a zatim primijeniti odredbe $\mathrm{ZV}$-a kao lex specialis ako su ispunjene za to pretpostavke prema kriterijima i stajalištima koji su izneseni, uz podrednu primjenu propisa obveznog prava. Tek ako nisu ispunjene pretpostavke za primjenu ZV-a kao lex specialis može doći do direktne $\mathrm{i}$ isključive primjene odredaba ZOO-a, također pod pretpostavkom ispunjenja pretpostavki za njihovu primjenu.

\section{ZAKLJUČAK}

Pravni položaj posjednika stvari prema vlasniku stvari ovisi ponajprije o tom radi li se o poštenom ili nepoštenom posjedniku. Pošteni posjednik ima daleko povoljniji položaj nego nepošteni posjednik, te je njegova jedina obveza predaja stvari vlasniku na njegov opravdani zahtjev. On nije obvezan dati naknadu za uporabu i koristi koje je imao od stvari, a nije dužan naknaditi vlasniku ono što je pritom oštećeno ili uništeno. Nepošteni posjednik, osim obveze predaje stvari vlasniku, dužan je naknaditi sve štete koje su nastale na stvari kao i sve koristi koje je imao od stvari uključujući i one koje je zanemario ostvariti. Pošteni posjednik ima i daleko veća prava prema vlasniku stvari, pa tako ima pravo na naknadu nužnih i korisnih troškova, pravo zadržanja stvari radi osiguranja naplate svog potraživanja te pravo odnošenja u odnosu na tzv. luksuzne troškove. S druge strane, nepošteni posjednik ima pravo potraživati samo nužne troškove pod uvjetom da bi oni bili nužni i samom vlasniku te ima pravo odnošenja za troškove koji mu se ne naknađuju.

Potraživanja vlasnika stvari prema nepoštenom posjedniku kao i potraživanja poštenog i nepoštenog posjednika prema vlasniku stvari zastarijevaju u roku od tri godine od predaje stvari vlasniku. Odredbe $\mathrm{ZV}$-a su lex specialis u odnosu na propise obveznog prava te je njihova primjena samo supsidijarna u odnosu na ono što nije regulirano u ZV-u. Pretpostavke za primjenu odredbi ZV-a koje reguliraju pravni položaj posjednika prema vlasniku stvari su: da se potraživanja moraju temeljiti na ulaganjima i troškovima koje je posjednik imao za vrijeme posjedovanja vlasnikove stvari, da je vlasnik stvari zatražio predaju stvari ili je stvar dobrovoljno predana vlasniku i da prava i obveze između vlasnika i posjednika stvari nisu drukčije regulirana pravnim poslom.

74 V. sudsku praksu navedenu supra kod bilj. 45. 


\section{LITERATURA}

1. Crnić, I.; Zakon o obveznim odnosima, Napomene, komentari, sudska praksa i prilozi, III izdanje, Organizator, Zagreb, 2006.,

2. Gavella, N. et al.; Stvarno pravo, Svezak 1, II izmijenjeno i dopunjeno izdanje, Narodne novine, Zagreb, 2007.,

3. Gorenc, V. et al; Komentar Zakona o obveznim odnosima, Narodne novine, Zagreb, 2014.

4. Jelčić, O.; Tužbe radi zaštite prava vlasništva, Hrvatska pravna revija, 2001.

5. Jug, J.; Tužbe za zaštitu prava vlasništva, Aktualnosti hrvatskog zakonodavstva i pravne prakse, Godišnjak 19, Organizator, Zagreb, 2012.,

6. Klarić, P. i Vedriš, M.; Građansko pravo, Opći dio, stvarno pravo, obvezno i nasljedno pravo, IX izmijenjeno i dopunjeno izdanje, Narodne novine, Zagreb, 2008.,

7. Žuvela, M.; Vlasničkopravni odnosi, Zakon o vlasništvu i drugim stvarnim pravima, Zakon o zemljišnim knjigama, Prateći propisi, pravna pravila, sudska praksa, prilozi i kazala, III izmijenjeno i dopunjeno izdanje, Organizator, Zagreb, 2009. 


\section{Summary}

\section{THE LEGAL POSITION OF HONEST AND DISHONEST POSSESSORS IN RELATION TO THE OWNERS OF THINGS}

This paper deals with the problems related to the legal position of honest and dishonest possessors in relation to the owner of things, that is, it analyses the rights belonging to the possessors of things and the demands that possessors may require from the owners of things to whom the possessors must submit those things. Also, in contrast, the rights and requirements are analysed of the owners of things in relation to honest and dishonest possessors. In practice, a dilemma arises in defining the essential and beneficial expenditure incurred by honest possessors, what the presumptions are for and until when the right of retention may be exercised for the sake of remuneration of that expenditure, when the statute of limitations expires on that claim, and the significance of the provisions of the Civil Obligations Act in relation to unjust enrichment, management without mandate and the right of retention, and which provisions regulate these or similar issues. The answers to some of these dilemmas have been provided in case law, and therefore the basic method used in the paper was analysis and research of case law, especially decisions by the Supreme Court of the Republic of Croatia.

The introduction to the paper provides the basic characteristics of the concept of possession and possession of things, and the type and quality of possession, to provide a basis for the subsequent analysis of the legal position of the possessor of a thing in relation to the owner of that thing.

Keywords: honest possessor, dishonest possessor, essential and beneficial expenditure, legal retention, unjust enrichment, statute of limitations.

\section{Zusammenfassung}

\section{DIE RECHTSPOSITION DER EHRLICHEN UND UNEHRLICHEN BESITZER IN BEZUG AUF EIGENTÜMER}

Diese Arbeit beschäftigt sich mit den Problemen, die mit der rechtlichen Stellung ehrlicher und unehrlicher Besitzer im Verhältnis zum Eigentümer verbunden sind, d.h. sie analysiert die Rechte des Besitzers und die Forderungen, welche der Besitzer vom Eigentümer verlangen kann, damit der Besitzer sein Besitz abgibt. Im Gegensatz dazu werden die Rechte und Anforderungen des Eigentümers in Bezug auf ehrliche und unehrliche Besitzer analysiert. In der Praxis entstehen Dilemmas, wie die wesentlichen und vorteilhaften Ausgaben des ehrlichen Besitzers bestimmt werden, welche 
Voraussetzungen es sind und bis zu welchen Zeitpunkt das Zurückbehaltungsrecht für die Vergütung dieser Ausgaben ausgeübt werden kann, wann die Verjährungsfrist anfängt und von welcher Bedeutung die Bestimmungen des Zivilverfahrensgesetzes in Bezug auf die ungerechte Anreicherung, die Geschäftsführung ohne Anordnung oder das Zurückbehaltungsrecht sind und welche Bestimmungen diese und ähnliche Fragen regeln. Die Antworten auf einige von diesen Dilemmas sind in der Rechtsprechung vorgelegt, weshalb die Analyse und Forschung der Rechtsprechung, insbesondere Entscheidungen des Obersten Gerichtshofs der Republik Kroatien, die grundlegende Methode dieser Arbeit ist.

In der Einführung bietet diese Artikel die grundlegenden Merkmale des Begriffs des Besitzens und des Eigentumsbesitzes und die Art und Qualität des Besitzes an, um eine Grundlage für die anschließende Analyse der Rechtsposition des Eigentumsbesitzers in Bezug auf den Eigentümer zu schaffen.

Schlüsselwörter: ehrlicher Besitzer, unehrlicher Besitzer, wesentliche und nützliche Ausgaben, gesetzliche Aufbewahrung, ungerechtfertigte Bereicherung, Verjährung.

Riassunto

\section{LA POSIZIONE GIURIDICA DEL POSSESSORE DI BUONA E DI MALA FEDE RISPETTO AL PROPRIETARIO DEL BENE}

Nel lavoro si disamina la questione relativa alla posizione giuridica del possessore di buona fede e di quello di mala fede rispetto al proprietario del bene: ovvero si analizzano i diritti riconosciuti al possessore del bene e le pretese che il possessore può avanzare nei confronti del proprietario al quale il possessore debba consegnare il bene. Altresì si esaminano dall'altra parte anche le pretese del proprietario nei confronti del possessore di buona fede o di quello di mala fede. Nella prassi emergono perplessità circa la determinazione delle spese necessarie ed utili, sostenute dal possessore di buona fede, quali siano i presupposti delle stesse e fino a quando si possa far valere il diritto a ritenere il bene per il soddisfacimento delle predette spese; ancora, perplessità circa il momento in cui intervenga la prescrizione di detti crediti e di quale rilevanza siano le disposizioni della Legge sui rapporti di obbligazione con riguardo all'arricchimento senza giusta causa, alla gestione di affari altrui od al diritto alla ritenzione, posto che queste ultime norme regolano una questioni simili od eguali. Le risposte ad alcune di queste perplessità sono state date dalla giurisprudenza; pertanto, il metodo d'indagine adottato nel presente lavoro è quello dell'analisi e della ricerca della giurisprudenza, con particolare attenzione alle decisioni della Suprema corte della Repubblica di Croazia. In via introduttiva nel lavoro si indicano le fondamentali caratteristiche della nozione di possesso e del possesso di cose e dei tipi e delle caratteristiche del possesso; tutto ciò al fine di 
analizzare successivamente la posizione giuridica del possessore del bene rispetto al proprietario del bene.

Parole chiave: possessore di buona fede, possessore di mala fede, spese necessarie ed utili, diritto di ritenzione, arricchimento senza causa, prescrizione. 